\title{
先天股脱における田蓋の発育について
}

長崎大学整形外科

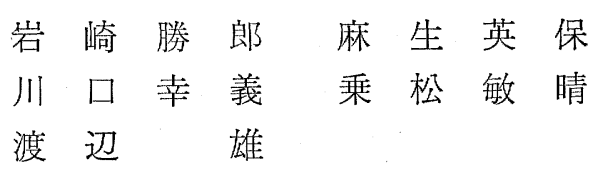

\section{Acetabular Development in Congenital Dislocation of the Hip}

By

\author{
K. Iwasaki, H. Asô, Y. Kawaguchi, \\ T. Norimatsu \& T. Watanabe \\ Department of Orthopedic Surgery Nagasaki \\ University School of Medicine
}

\begin{abstract}
Acetabular development in the congenital dysplasia and dislocation of the hip was discussed by measurement of the acetabular angle, which were treated at Nagasaki University Hospital during the period from 1964 to 1968.

Conclusions were as follow.

1. In the cases of dysplasia and dislocation treated by Pavlik method (97 cases, 103 hips) acetabular development was good, if the treatments were begun within 5 monthes after birth.

2. In the cases of dislocation treated by plaster cast fixation (56 cases, 63 hips), degree of improvemet of the acetabular angle was not satisfactory in $82 \%$. In these unsatisfactory cases, inverted limbus were found in $92 \%$ by arthrogram of the hip, but when manual reductions were done, these limbus have been pressed against acetabular roof by femoral head.

3. In the cases which were surgically reduced with limbectomy, none of all cases had good acetabular development.

4. It is thought that factors influencing the acetabular development are age of initital treatment, concentricity of the femoral head and shape of the limbus.
\end{abstract}

\section{はじめに}

先天股脱において臼蓋は骨頭が求心位に保持されて いさえすれば 良好な発育をとげるといわれているが (Somerville, Wilkinson, Scaglietty, 牧野など), 一方 Ponseti は自蓋発育の程度や速度は各症例によ って非常に差があるがその原因は不明であるとし，ま

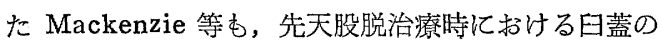
発育は予測できないとのべている. Schwartz は骨頭 が求心位に長期間保持されていても，必ずしあ良好な 曰蓋が得られるとはかぎらないし，更に臼蓋形成の良 否が先天股脱の予後とよく一致するとしてその重要性
を強調している.

このように蓋の発育に関しては，骨頭の整復後で あ必ずしあ楽観視できない点もあり，いまだ discussible な問題といわねばならない，われわれは経時的 に蓋角の計測を行なってその発育状態を観察し，更 に発育障害の原因について考察を加えた.

\section{調査対象及び方法}

長崎大学整形外科に扔いて, 昭和 39 年より昭和 43 年の 5 年間に治療した先天股脱 357 例の内, 少なくと も 1 年以上経過観察のできた 160 例， 209 関節を対象 とした. これを I 群; Dysplasia-Riemenbügel (以 
後 R. B) 治療例 20 例, 36 関節, II 群; 脱曰-R. B 治療例 72 例, 97 関節, III 群; 脱曰一徒手整復ギプス 固定例 56 例, 63 関節, $\mathrm{IV}$ 群; 観血的整復術施行例 12 例, 13 関節の 4 群にわけ, 各々の症例に対して経時 的に曰蓋角を測定した. その測定に当っては, 目蓋の 外下端に $\mathrm{E}$ 点をとるのではなくて, 森田らが指摘した 如く, レ線上王蓋像が二重にみえる場合, 上部の（即 ち後縁）日蓋線で，それが滑脱溝またはそれの痕跡へ 移行する点に $\mathrm{E}$ 点を求めて計測した。

\section{調 査 成 績}

臼蓋角の正常值は 報告者によってまちまちである が，われわれは生後一年以内では一応 $30^{\circ}$ をむって正 常值の限界亡した.

I 群; Dysplasia-R. B 治療例は全例 6 ケ月以内に 治療が開始されているが, 治療開始月別にわけて毛蓋 角の平均值を算出し発育の状態をみてみると, 図 1 亿 みる如く全例が同様の曲線老描いて減少していき，約 2 ケ月後には $74 \%$ が， 7 ケ月後には全例が $30^{\circ}$ 以下 になった。

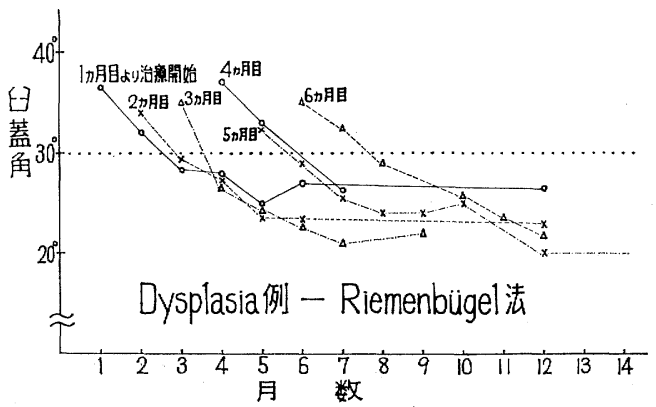

図1治療開始時期よりみた日蓋角の推移

II群; 脱曰-R. B 治療例飞 おける治療開始時期別 関節数は生後 1 ケ月 $10 ， 2$ ケ月 $14 ， 3$ ケ月 $38 ， 4$ ケ 月 13,5 ケ月 $14 ， 6$ ケ月 $6 ， 7$ ケ月 2 であった. こ 机らに対してI群之同様に四蓋角の平均值をとってみ ると，図 2 の如き四蓋の発育状況を示している。 つま り，I群の曲線ほど急ではないにしても，治療開始が 5 ケ月以内であればある一定のパターンで発育してい るが，開始が $6 ， 7$ ケ月となると日蓋発育はかなり遅 延してくる．次に $30^{\circ}$ 以下に達するのに要した期間之 治療開始月数との関係について調べたのが図 3 である が，5 ケ月以内に開始すると $84 \%$ 開始後 7 ケ月以 内に $30^{\circ}$ 以下になっているが，6 ケ月以後に開始した

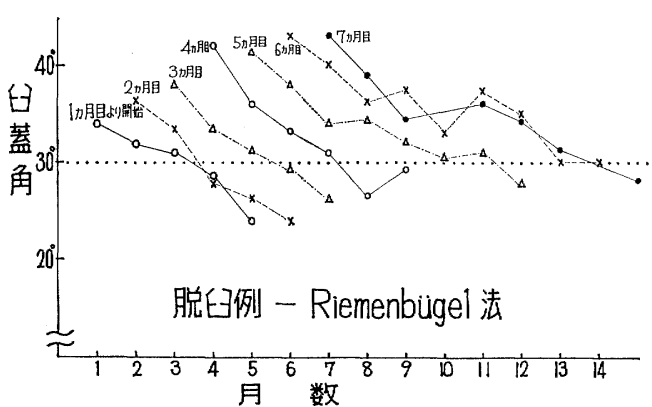

図2 治療開始特期よりみた日蓋角の推移

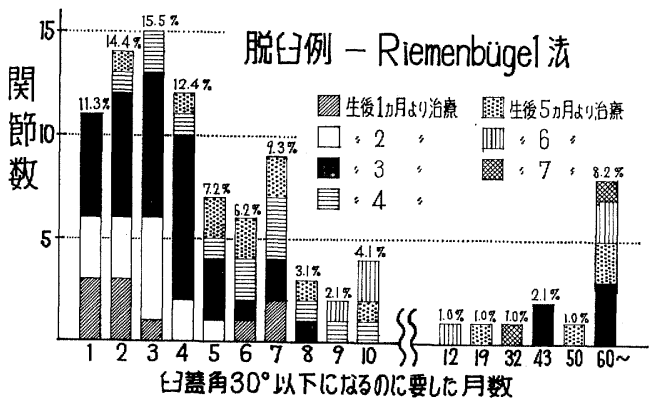

図3日蓋角 $30^{\circ}$ 以下になるのに要した 月数と治療開始月数との関係

場合には，2才までの間にその半数しか良好な発育を 示していないままたての群に执いて，5才以上にな ってあ目蓋形成不全がみられたのが $8.2 \%$ あった。 の中には 3 ケ月目に治療を開始したものがあったが， 造影により関節唇によると思われる日底肥厚がみられ た.

III群；徒手整復ギプス固定例は一般的に治療開始が 招そく，乙れらを 6 ケ月毎の治療開始時期別にわける とその関節数は, 生後 $1 \sim 6$ ケ月 $17,7 \sim 12$ ケ月 6 , 13〜18 ケ月 39,19 ケ月以上 12 で，13〜18 ケ月開始 例が圧倒的に多い，乙の時期別にわけた各グループ每 の症例に対して 1 年間隔で曰蓋角を測定しその平均值 をグラフに示した. (図4). 当然のととながら，1〜 6 ケ月の間に治療を開始したあのは，その後 1 年間に 且蓋は良好祮発育をするのに反して，7 ケ月以後汇開 始したものはその後の 1 年間に曰蓋角は減少してはい くあのの，その速度は緩慢であり 5 ～6才になっても 形成不全を残したものが $82 \%$ はられた。

乙の III 群 63 関節の内 48 関節に 股関節造影が行な わ机 44 関節 $(92 \%)$ 亿内反した関節唇をみとめてい るが，乙れらはそのまま徒手整復後ギプス固定され内 


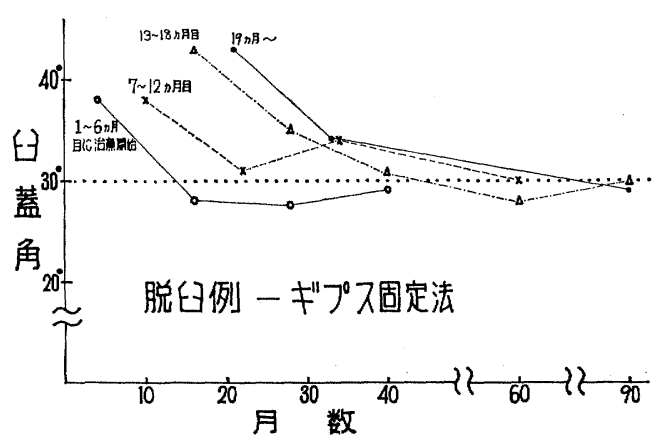

図4治療開始時期よりみた日蓋角の推移

反した関節唇は，日底におしつけられたままの状態で 以後経過していった。

IV 群; 観血的整復術施行例は症例数が少ないため 平均值ではなくて, 各症例毎に臼蓋角の変化をグラフ に示した(図 5 ). 関節唇の切除を行なって骨頭の求心 性を確保したと思える症例でも目蓋角は術前之殆んど かわりなく，中にはかえって急峻化しているものもあ り大半は予防的臼蓋形成術がその後行なわれた。

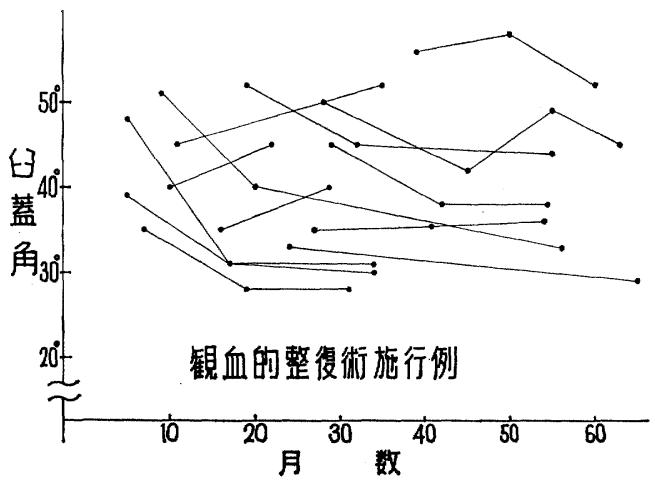

図 5

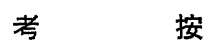

森田らは正常股関節の日蓋角が年令と共に発育して いくさまをグラフに示しているが，乙のシリーズにお いてむ，I群の全例 及び II 群の大部分はこれと似た ような発育のパターンを示している．しかし II 群の 一部には 2 个月で R.B. 亿よる治療を開始したにもか かわらず，5才以上になってもまだ曰蓋形成不全が残 存している例あみられた，乙れらは R.B にて一応 initial reduction 亿は成功し 単純レ線では一見求心 位に保持されているようにみえるすのの，造影を行な
うと曰底の肥厚をみとめたととからも, 整復時関節唇 が因底に招しつけられた状態になり，そのため骨頭の 求心位保持は不完全であったあのと考えねばならな い.

III 群はその治療開始時期が II 群に比して非常に遅 いため, 両治療法のちがいによる田蓋発育の比較は出 来なかったが， III 群内での治療開始時期のちがいに 上る日蓋発育の差は， I，II 群之同様にみられ，6 ケ 月以内に開始したものに比してそれ以後の症例の日蓋 発育は非常に 悪くなっている． III 群の内股関節造影 により 44 関節 $(92 \%)$ に内反した関節唇を証明し た. また関節唇の内反がみられなかった 4 関節の内 3 関節は 6 ケ月以内に治療を開始したすのである．以上 の造影记関するデーターより, R. B. 不成功例屯含め て, 治療開始が 6 ケ月以後になった先天股脱の少なく とも $90 \%$ 以上は関節唇の内反がみられると考えてよ いと思う. 乙れらに対して徒手整復, ギプス固定を行 なった場合，関節唇は骨頭により因底におしつけら れ, 山田の分類によれば下垂型から日底肥厚型に移行 し，時の経過之共に関節唇は次第に萎縮扁平化してい きついには日蓋の関節軟骨之密に癒着し剝離は困難と なる.われわれは経時的行行なわれた股関節造影や手 術所見より以上のような関節唇の運命を観察すること ができた.

さて III群に执いて日蓋発育不良の原因は，年令的 に高いという点と共に，関節唇の形態の異常之それに あとづく骨頭の求心性保持の不完全さにあるとまず考 えられる. それで, IV群は求心性保持のため観血的に 関節唇，円鞀帯， fibrofatty tissue などを切除した 症例であるが，日蓋の発育は依然として改善されない 例が殆んどであり，また中にはかえって急峻になって いる例もある．乙のことは骨頭を求心位保持したの みでは必ずしあ良好な曰蓋発育をするとはかぎらない というSchwartz の意見をうらづけしている。 そし てての原因は関節唇を切除したためと考えるのが妥当 であろう.

日蓋の発育に関与する因子として，年令及び骨頭の 求心性ということが従来云われてきており，それはて のシリーズに扔ける I， II 群に扔いてあ証明された が，III， IV 群に 执いては，内反した関節唇があった 場合，それを目蓋注しつけてあ悪いし切除しても悪 いという結果になった。このととは関節唇の形態の異 常や存在の有無が日蓋の発育に影響するあのだと考え 
てよいであろう。

変形性股関節症の発生には丢の発育が最む重要だ といわれているが，先天股脱に打いて目蓋の形成を良 好ならしめるためには，早期に，完全な求心位保持を 最大の目的とすべきであるが，そのためにとられる処 置の一つとしての観血的整復術你しては，内反した 関節唇の処理の方法に問題点があると考えられ今後検 討を加えたい。

\section{結語}

昭和 39 年より昭和 43 年の 5 年間に長崎大整形外科 にて治療した先天股脱のうち，Dysplasia-R. B 治療 例 36 関 節, 脱曰一R. B 治療例 94 関節, 脱曰一ギプ ス固定例 69 関節, 観血的整復術施行例 13 関節に対し て経時的に蓋角を測定し次の結論をえた.

(1) R. B で治療された Dysplasia 及び脱臼例は， 治療開始が早ければ（5 ケ月以内）日蓋はほぼ良好な 発育をする。

(2) 脱臼一ギプス 固定例では $82 \%$ 白蓋発育は不 良であった．乙れらは股関節造影により内反した関節
唇を $92 \%$ みとめているが, 徒手整復される際これ ら関節唇は骨頭により日底に执しつけられていた。

(3) 観血的整復術施行例では, 術後良好な曰蓋形成 を示したものは一例むなかった。

(4) 日蓋発育関与する因子として, 年令, 骨頭の 求心性及び関節唇の形態や存在の有無がきわめて重要 なものとしてあげられる。

\section{参 考 文 献}

1) Mackenzie, I. G. et al. : J. B. J. S. 42-B : 689,1960

2) Ponseti, I. V. : J. B. J. S. 48-A : 1392, 1966

3) Scaglietii, O. et al. : J. B. J. S. 44-B : 257, 1962.

4) Schwartz, D. R. : J. B. J. S. 47-A:705, 1965.

5) Somerville, E. W.: J. B. J. S. 39-B : 623, 1957.

6) Wilkinson, J. et al. : J. B. J. S. 42-B : 669, 1960.

7）赤星：整形外科. $20: 726$, 昭44.

8) 牧野: 整形外科. $15: 935$, 昭39.

9）森田・他：日外宝函. $37: 333,1968$.

\title{
先天性股関節脱臼のペルテス様変化について
}

$\begin{array}{cccc}\text { 九州大学整形外科 } & & \\ \text { 光 } & \text { 安 } & \text { 夫 } \\ \text { 松 } & \text { 尾 } & & \text { 隆 }\end{array}$

Osteochondritis in Congenital Dislocation of the Hip.

By

\author{
M. Mitsuyasu \& T. Matsuo \\ Department of Orthopedic Surgery, Faculty \\ of Medicine, Kyushu University
}

In the six-year-period from 1953 to 1959, 262 patients with the congenital dislocation or subluxation of the hips were seen at our outpatient clinic. The routine treatments in these years were to attempt manual reduction and to immobilize the dislocated hip in a frog-leg plaster during three or four months, after which gradual mobilization was allowed.

Based on the analysis of the radiographic and clinical data of these cases, osteochondritis in the congenital dislocation of the hips was examined.

The results are as follows:

1. Thirty percent of the cases showed similar findings to those of Legg-Perthes disease. 